\title{
An Early Warning Signal (EWS) Model for Predicting Financial Crisis in Emerging African Economies
}

\author{
Kehinde Damilola Ilesanmi ${ }^{1} \&$ Devi Datt Tewari ${ }^{1}$ \\ ${ }^{1}$ Department of Economics, University of Zululand, KwaDlangezwa, South Africa \\ Correspondence: Kehinde Damilola Ilesanmi, Department of Economics, University of Zululand, Private Bag X1001, \\ KwaDlangezwa, 3886, South Africa. Tel: 27-834-527-999.
}

Received: May 27, 2020

Accepted: November 10, 2020

Online Published: December 24, 2020

doi:10.5430/ijfr.v12n1p101

URL: https://doi.org/10.5430/ijfr.v12n1p101

\begin{abstract}
The devastating effects of the global financial crisis (GFC) have led to a renewed, global interest in the development of an early warning signal (EWS) model. The purpose of the EWS model is to alert policymakers and other stakeholders to the possibility of the occurrence of a crisis. This study estimates a EWS model for predicting the financial crisis in four emerging African economies using a multinomial logit model and a data set covering the period of January 1980 to December 2017. The result of the study suggests that emerging African economies are more likely to face financial crisis as debts continue to rise without a corresponding capacity to withstand capital flow reversal as well as excessive foreign exchange risk due to currency exposure. The result further indicates that rising debt exposure raises the likelihood of the economies remaining in a state of crisis. This result confirms the significance of a financial stability framework that addresses the issues confronting Africa's emerging economies such as rising debt profile, liquidity and currency risk exposure.
\end{abstract}

Keywords: Early Warning Signal (EWS), financial crisis, logit, multinomial

\section{Introduction}

The 2007/08 global financial crisis (GFC) which emanated from the United States and spread to other developed and emerging countries resulted in large-scale losses in most economies around the globe (Cunningham and Friedrich, 2016; Ilesanmi and Tewari, 2019a). The devastating effects of the GFC have led to a renewed, global interest in the development of an early warning signal (EWS) model with the purpose of alerting policymakers and other stakeholders to the possibility of the occurrence of a crisis (Ilesanmi and Tewari, 2019b).

Determining the state of the financial system is very important for the design of appropriate policy such as countercyclical capital buffers which can assist in reducing losses accompanying the financial crisis (Drehmann and Juselius, 2014; Louzis and Vouldis, 2012). In order to predict systemic risk in the financial system, an EWS model built by Bussiere and Fratzscher (2006) was adopted to afford policymakers a sufficient period to avert or mitigate the impact of the potential financial crisis (Louzis and Vouldis, 2012; Oet, Bianco, Gramlich, and Ong, 2013). The EWS model is used primarily to predict the possibility of the occurrence of a crisis though it might not predict the exact time of the crisis (Caggiano, Calice, and Leonida, 2014).

For the EWS, the multinomial logit model was adopted. This method is commonly used in the literature compared to the binomial logit model which is usually subject to post-crisis bias. This is because the binomial logit model does not differentiate the three crisis phases: tranquil period, crisis period and post-crisis period. The multinomial logit model was used by Bussiere and Fratzscher (2006) within a currency crisis framework, while Oet et al. (2013) and Caggiano et al., (2014) applied it within a banking crisis framework. In these studies, the model was used to predict the probability of the occurrence of a crisis (which takes the value of 1 for the first crisis year, 2 for the other crisis years (Note 1) and 0 for non-crisis years), as a function of a vector of several independent variables.

Despite growing literature on the development of EWS models, emerging African economies have not received any specific attention in that regard. Most of the previous studies have been subject to survey-based qualitative analysis (Daumont, Le Gall, and Leroux, 2004; Caggiano et al., 2014) and cross-country panels, pooled together with other emerging economies or advanced economies (Davis and Karim, 2008; Drehmann and Juselius, 2014; Oet et al., 2013). According to Van den Berg, Candelon, and Urbain, (2008), building an EWS model for economies with homogenous characteristics performs better than when they are pooled together with other countries outside the region. While most previous studies have focused on developed countries which were the most severely affected by the crisis (Babecky, 
Havranek, Mateju, Rusnak, Smidkova, and Vasicek, 2014; Barrell, Davis, Karim, and Liadze, 2010), a number of studies have been done on emerging economies and low-income countries (Caggiano, et al., 2014). However, none of these studies has focused on emerging African economies (EAEs).

This is a gap that this study intends to fill since most EAEs also experienced a number of crises or were affected directly and indirectly by the crisis. This study uses a EWS model to predict financial crises in EAEs for four EAEs, namely, Egypt, Kenya, Nigeria and South Africa. Our findings indicate that debt exposure variables are major predictors of financial crisis in EAEs. EWS models are of great value to policymakers and other stakeholders as they help in detecting underlying economic vulnerabilities within the region and facilitate steps to either mitigate the effects of economic downsides in the event of a crisis.

The remainder of this paper is organised as follows: Section 2 presents the literature review while Section 3 focuses on the methodology and data used in the study. Section 4 presents the empirical results of the multinomial model estimation, while conclusion and policy recommendation are in Section 5.

\section{Systemic Risk and EWS}

Systemic risk is an integral element in the design and implementation of macroprudential policy. Basically, systemic risk is the possibility of the occurrence of events resulting in the obstruction of the ability of the financial sector to supply credit in the economy (Yellen, 2011). It is the risk of disruption to financial services which is caused by an impairment of all parts of the financial system with the possibility of having severe adverse consequences for the real economy (Brockmeijer et al., 2011; Foggitt, Heymans, van Vuuren, and Pretorius, 2017). Such events, which are driven mainly by economic and financial cycles over time, as well as by the degree of interconnectedness of financial institutions and markets, are capable of creating anxiety within the system, thereby leading to the failure of the financial institution and, ultimately, the collapse of the whole system (Krishnamurti and Carol, 2014). However, whether financial failures are sources of systemic risk or not is contingent on the performance or influence of the rest of the financial system on the economy. This means that the disruption of the financial sector is not the only source of systemic risk, but it can be a major factor. For example, the 1987 stock market bubble (fuelled by leverage trades) in the United States led to systemic risk, while, on the other hand, the dot.com bubble did not lead to any systemic risk, due to limited systemic exposure (Brockmeijer et al., 2011). Similarly, the 1998 Long Term Capital Management (LTCM) crisis is an example of an event bearing systemic risk, while the fall of Amaranth Advisors in 2006 did not bring the threat of significant impairment of the financial system (Brockmeijer et al., 2011). It has been argued that not every identified credit boom is linked to systemic risk (Brockmeijer et al., 2011).

The development of the EWS models was mainly to evaluate the likelihood of the occurrence of crisis using quantitative or econometric techniques. Basically, there are two types of EWS model, namely, the composite indicator model and the logit/probit model (Bhattacharyay et al., 2009). Whereas the composite indicator builds a composite index using the number of warning signals obtained from a set of macroprudential indicators and directly linking it with a probability of crisis, the probit or logit model computes a probability of the occurrence of a crisis based on the reaction of indicators prior to crisis periods (Bhattacharyay et al., 2009). For example, Frankel and Rose (1996) suggested the use of binomial logit or probit regression models for the estimation of the probability of an impending currency crisis. Wong et al. (2010) employed the probit model for 11 Asia-Pacific countries, and their findings revealed that credit growth contributes greatly to the build-up of systemic banking problems.

Previously, Demirguc-Kunt and Detragiache (1998) suggested that banking crises are oftentimes preceded by rapid credit growth within a time-frame of two years. In the case of developed economies, Barrel et al. (2010) constructed an EWS model for banking crises using the logit model. The result showed that house price growth and leverage ratios, as well as liquidity ratio, are determinants of banking crisis in Organisation for Economic Co-operation and Development (OECD) member countries. However, Schimmelpfennig, Roubini, and Manasse, (2003) opined that in situations where the regressed variable is not equitably distributed amongst the dichotomy outcomes, (that is, crisis and no crisis), the logit model tend to outperform the probit model.

Furthermore, there have been attempts to integrate the binomial and multinomial logit models by employing the binary classification procedure (Duttagupta and Cashin, 2008) as well as the estimation of bank fragility using the credit risk model based on the stock market (Eichler et al., 2011; Eichler and Sobanski, 2012). It is however abundantly clear from empirical studies that the multinomial logit model performs better than others. The binomial approach is prone to both type I (missed crises) and type II errors (false alarms).

In addition, EWS indicators are likely to react inversely during periods of tranquillity in comparison to periods after the crisis. During the periods after the crisis the economy undergoes a correction process to recuperate from the damage caused by the crisis. Therefore, lumping up the observations for the periods of tranquility together with that of the periods after the crisis into a single zero (0) group is likely to result in what is known as "post-crisis bias" (Bussiere and 
Fratzscher, 2006). In order to avoid this "post-crisis bias," some authors (Fuertes and Kalotychou, 2007; Savona and Vezzoli, 2015) excluded such observation (that is, to drop all the post-crisis observation from the data). However, this may lead to information loss. On the other hand, Schimmelpfennig et al., (2003) employed a dummy variable to capture the coefficient of the post-crisis period. However, Bussiere and Fratzscher (2006) proposed that a multinomial crisis variable should be used in the place of a dummy variable to mirror all three periods or phases of the economy. They estimated the multinomial logit model with three regimes to predict most of the currency crisis in the emerging markets during the 1990s in both the in-sample and out-of-sample estimates. Although, the in-sample estimation could not predict one of the emerging market crises, it can be concluded that the multinomial approach is still superior since it captures the crisis and post-crisis period as well as predicting the time the economy takes to return to a tranquil regime.

In the same vein, Caggiano et al., (2014) employed a multinomial logit analysis for the EWS model in low-income economies for the period 1980 to 2008. Their study revealed that the multinomial logit estimation outperforms that of the binomial logit model in its predictive power in both the in-sample and out-of-sample estimation. The results further show that cases of crisis in low-income economies are usually linked to low economic growth, which resultantly puts enormous pressure on liquidity in the banking sector. Oet et al., (2013) developed a hybrid class of model based on the existing microprudential and macroprudential EWS models for systemic risk that incorporates the structural characteristics of the financial system to explain financial stress. Based on the findings of the study, a model known as the Systemic Assessment of Financial Environment (SAFE) EWS was developed to monitor the build-up of macroeconomic stress in the financial market. Additionally, with respect to the need to mitigate inherent uncertainty in the system, a medium-term forecasting specification which gives policymakers ample time to take action was developed.

Cumperayot and Kouwenberg (2013) employed the extreme value theory (EVT) in the context of currency crisis using 18 indicators for predicting a crisis in 46 countries between the years 1974 and 2008 . The study revealed that economic variables with a stronger relationship with the exchange rate can better be used to predict crisis both for the in-sample and out-of-sample estimation. Jedidi (2013) also employed a panel Logit model to develop an EWS model for 60 emerging and developed countries from $1970-2010$. The study identified various macroeconomic and financial variables that are capable of signaling the occurrence of a crisis to develop the model. Using different methodologies, it was revealed that total debt as a percentage of GDP, total gross external debt as a percentage of GDP, foreign exchange reserves, and Imports as a percentage of GDP are the most reliable early warning indicator of debt crisis. Furthermore, Dawood et. al. (2017) examined the predictive power of the econometric model in predicting the sovereign debt crisis using an early warning signal model for both developed and emerging economies. The findings of the study, which was found to be more precise in comparison to previous studies, show that in constructing an effective EWS model for the sovereign debt crisis, it is important to incorporate variables that capture and account for the likelihood of a spillover from the financial system. Geršl (2018) also explored the role of credit-based variables as an indicator of banking crises in 36 emerging economies. Findings of the study indicate that credit growth and the ratio of credit to GDP ratio are the major early warning indicators of crisis.

\section{Methodology and Data}

Given the purpose of this study, the multinomial logit model was adopted to estimate the EWS model for predicting the financial crisis in four emerging African economies. Specifically, each economy $i=1, \ldots . n$ can be in one of the following state: tranquil period $(j=0)$, first year of crisis $(j=1)$, or crisis years after the initial crisis year $(j=2)$. The probability of the economy being in a state of $j$ is given by:

$$
\operatorname{Pr}\left(Y_{t}=j \mid X_{i, t}\right)=\frac{e^{\beta^{\prime} j^{\prime} X_{i, t}}}{1+\sum_{l=1}^{J} e^{\beta^{\prime} X^{X} X_{i, t}}}, \beta_{0}=0, J=2
$$

where $X_{i, t}$ is the vector of regressors of dimension $K$ and $\beta$ is the vector of parameters to be estimated. Equation 2 gives the $\log$-likelihood function to be maximised.

$$
\operatorname{Ln}(L)=\sum_{i=1}^{n} \sum_{j=0}^{j} d_{i j} \ln \operatorname{Pr}\left(Y_{i}=j\right)
$$

where $d_{i j}=1$ when the economy $i$ is in state $j$

Setting the tranquil period as the base outcome in order to allow for the identification of the multinomial logit model gives the following $j=2 \log$-odds ratio: 


$$
\frac{\operatorname{Pr}\left(Y_{i, t}=1\right)}{\operatorname{Pr}\left(Y_{i, t}=0\right)}=e_{1}^{\beta^{\prime}} X_{i, t}
$$

and

$$
\frac{\operatorname{Pr}\left(Y_{i, t}=2\right)}{\operatorname{Pr}\left(Y_{i, t}=0\right)}=e_{2}^{\beta^{\prime}} X_{i, t}
$$

In Equation (3), the vector of the parameter $\beta_{1}$ measures the impact of the variation in the explanatory variables $X_{i, t}$ on the likelihood of the occurrence of a systemic financial crisis in comparison to the likelihood of remaining in tranquil state. On the other hand, in Equation (4), $\beta_{2}$ measures the impact of the variation in the explanatory variable $X_{i, t}$ on the likelihood of remaining in a crisis state in comparison to the likelihood of being in tranquil state.

Data used in this study include the real gross domestic growth rate (RGDPG), inflation (INFR) and exchange rate depreciation (EXHR) to measure economic activities, macroeconomic stability, and foreign exchange risk respectively. High inflation affects the return on assets negatively and discourages savings, which raises the likelihood of experiencing crisis. Exchange rate depreciation is likely to undermine the stability of the banking sector. Other variables include domestic credit to the private sector (DCRP) as a percentage of GDP, ratio of broad money to foreign exchange reserve (BMM2), foreign asset net open position (FXOP), debt to GDP ratio (DGDP), short term debts as a percentage of total debts (SDTD), , trade openness (TOP), foreign direct investment (FDI), and the financial stress index (FSI).

\begin{tabular}{|c|c|c|c|}
\hline Variable name & Description & Frequency/state & Measure \\
\hline RGDPG & The real gross domestic product growth rate & Annual/\% & $\begin{array}{l}\text { Economic } \\
\text { activities }\end{array}$ \\
\hline INFR & Inflation & Annual/\% & $\begin{array}{l}\text { Macroeconomic } \\
\text { stability }\end{array}$ \\
\hline EXHR & $\begin{array}{l}\text { The rate of change of the nominal exchange rate with } \\
\text { respect tothe US dollar. An increase indicates a depreciation } \\
\text { of the domestic currency }\end{array}$ & $\begin{array}{l}\text { Annual } \\
\text { average } / \%\end{array}$ & $\begin{array}{l}\text { Foreign } \\
\text { exchange risk }\end{array}$ \\
\hline BMM2 & $\begin{array}{l}\text { The ratio of M2 to foreign exchange reserves of the Central } \\
\text { Bank }\end{array}$ & Annual/\% & $\begin{array}{l}\text { Monetary } \\
\text { condition }\end{array}$ \\
\hline DCRP & Domestic credit to private sector (\% of GDP) & Annual/\% & $\begin{array}{l}\text { Monetary } \\
\text { condition }\end{array}$ \\
\hline FXOP & The ratio of net foreign assets to GDP & Annual/\% & Liquidity \\
\hline DGDP & Debt to GDP ratio & Annual/\% & Leverage \\
\hline SDTD & Short-term debt as a $\%$ of total debt & Annual/\% & Liquidity \\
\hline TOP & Trade openness (import+export)/GDP & Annual/\% & $\begin{array}{l}\text { International } \\
\text { trade }\end{array}$ \\
\hline FDI & Foreign direct investment, net inflows (\% of GDP) & Annual/\% & Capital flow \\
\hline FSI & Financial stress index & Annual/index & Financial risk \\
\hline
\end{tabular}

Table 1. Summary of variables

The ratio of money supply (BMM2) to official foreign reserves depicts the capacity of the economic system to endure a shock in capital flows, particularly during periods of currency peg (Caggiano et al. 2014). A higher value BMM2 would mean a higher level of exposure tooutflow of capital, and therefore a higher likelihood of experiencing a crisis in the banking sector. In the same vein, excessive credit growth (DCRP) can be challenging as this may lead to a general decline in asset quality and/or a decrease in liquidity, particularly when the funding sources are volatile. (See Table 1 for the summary of the variables used). The foreign asset net open position is the ratio of net foreign asset to GDP. A negative net foreign asset would mean that the country is a net borrower.

Debt as a percentage of GDP (DGDP) is a measure of leverage. A high ratio is an indication of a high risk of default. The ratio of short-term debt as a percentage of total debts (SDTD) of a country indicates the extent to which the country relies on short-term financing. In other words, it indicates the vulnerability of such economies to liquidity shocks. 
Trade openness (TOP) which is exports plus imports divided by GDP reflects the level of a country's integration with the world economy. Foreign direct investment (FDI) (Note 2) which is a significant early warning indicator of crisis incidence is measured as the net inflows as a percentage of GDP.

The dependent variable takes the values between 0,1 and 2 compared to the observed value of the binary crisis variable which is constrained to 0 or 1 . Months with crisis episodes are identified when the index (FSI) value exceed a threshold equal to the index mean. As noted earlier, the non-crisis years takes the value 0 , first year of crisis takes the value of 1 , while the other crisis year after the first year of crisis takes the value of 2 . The FSI was calculated using 13 indicators and grouped into four market segments: money, bond, equity, and foreign exchange. The FSI which is used to capture financial stress in the financial system is assumed to be the factor most responsible for the co-movement of the market-specific variables, identified by principal components (Ilesanmi and Tewari, 2019b). This was done using the principal component analysis (PCA). Through the PCA, a common component which is assumed to capture the stress is extracted from among many variables. That is, each of the indicators is believed to capture a proportion of financial stress. This factor, which is the first principal component (PC) becomes the FSI. All indicators were transformed into a scale of between zero and one $(0,1)$. The formula is presented below:

$$
z_{i j}=\frac{x_{i j}-\min _{j}\left[x_{i j}\right]}{\left.\max _{j}\left[x_{i j}\right]-\min _{j}\left[x_{i j}\right]\right]}
$$

where $x_{i j}$ is the $j t h$ value of the $i t h$ component of the FSI. This is done by subtracting the minimum value of the sample variable from each variable $i$ and then dividing it by its range.

The study employed annual data from 1980 to 2017 and were sourced from the World Bank development indicators apart from the FSI. The study focused on the four emerging African economies of Egypt, Kenya, Nigeria and South Africa. The sample was drawn from a list of the countries with the largest economies as well as the level of stock market development based on the S\&P Dow Jones Indices Country Classifications, 2014. However, it must be noted that Nigeria was grouped among the frontier economy, although it meets all the criteria for being grouped as one of the emerging African economies. STATA 15 software was used for the estimation. The summary statistics are presented in Table 2. The average domestic credit to private sector for the four emerging African countries is 47 percent of GDP, while the average inflation rate is 13.11 percent. Average real GD growth rate is 2.80 percent. Debt to GDP and short-terrn debt to total debts are 50 percent and 13 percent respectively.

Table 2. Summary statistics of the variables used

\begin{tabular}{llllll}
\hline Variable & Obs & Mean & Std. Dev. & Min & Max \\
\hline dcrp & 152 & 46.59 & 42.64 & 8.71 & 160.12 \\
\hline infr & 152 & 13.11 & 11.02 & -0.69 & 72.84 \\
\hline rgdpg & 152 & 2.80 & 5.01 & -30.79 & 33.74 \\
\hline bmm2 & 152 & 51.13 & 24.70 & 13.23 & 98.14 \\
\hline exhr & 152 & 13.95 & 39.18 & -34.22 & 347.55 \\
\hline fxop & 152 & 138.32 & 256.34 & -20.67 & 1213.92 \\
\hline dgdp & 152 & 50.01 & 40.84 & 4.13 & 228.37 \\
\hline sdtd & 152 & 12.79 & 10.75 & 0.00 & 46.18 \\
\hline fsi & 152 & 0.61 & 0.91 & 0.00 & 2.00 \\
\hline Top & 152 & 52.03 & 12.26 & 20.72 & 82.18 \\
\hline Fdi & 152 & 1.71 & 1.94 & -1.15 & 10.83 \\
\hline
\end{tabular}

\section{Estimation Result and Discussion}

The estimated result of the EWS model using the panel multinomial logit regression is presented in this section. The result of the EWS model estimated for emerging African countries is presented in Tables 3 and 4. It must be noted that the signs of the coefficients are to be interpreted with care. This is because, in the event of a shock in the system, there are two possible economic scenarios that are likely to play out within the system during the post-crisis period. In the 
first scenario, it is possible for the crisis to escalate after the first year of crisis. In such a case, it is expected that economic indicators will worsen. In the second scenario, as corrective measures are undertaken by the authorities, there is a likelihood that the economy will improve and return to the equilibrium state. However, according to Dawood et al (2017), it is impossible to predict which of the two scenarios is likely to play out ex-ante. This, therefore, "makes it difficult to form reasonable expectations regarding the signs of the coefficients during the post-crisis period" (Dawood et al., 2017: 23).

The result, based on the observed information matrix (OIM) optimisation technique for the standard error, is presented in Table 3. The OIM is the matrix of second derivatives, typically of the log-likelihood function and is based on asymptotic maximum-likelihood theory. It is usually preferred when estimating small or medium datasets. The OIM estimator of the variance-covariance matrix of the estimates (VCE) is built on asymptotic maximum-likelihood theory (Hardin, et al. 2007).

Table 3. EWS model 1 for emerging African economies

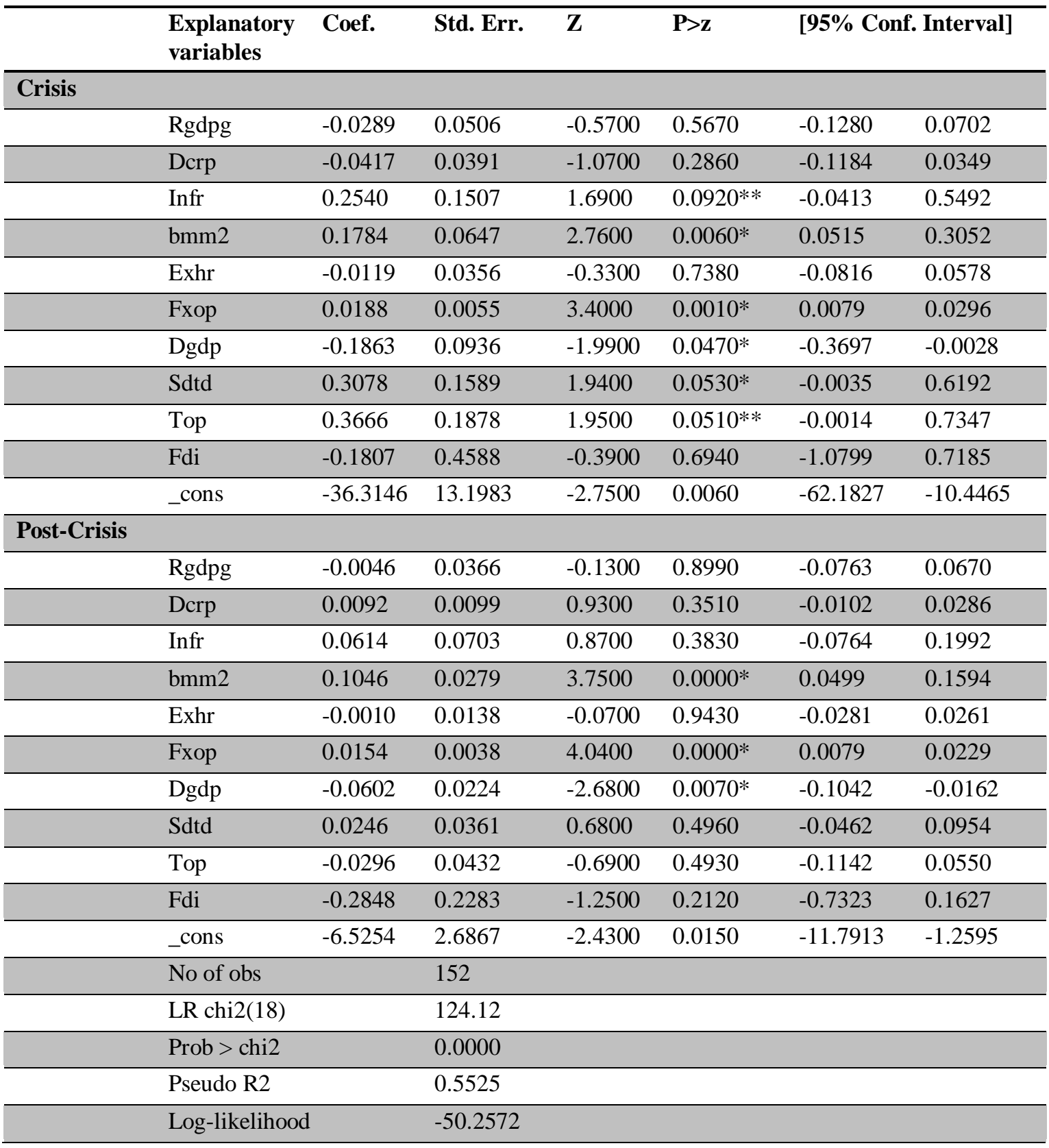


The result on the first panel of Table 3 is based on the likelihood of entering a crisis in comparison to remaining in a tranquil period (noting that the tranquil period was used as the base outcome in the estimation). This result indicates that the debt exposure variables (dgdp and sdtd) which are the ratio of debt to GDP and ratio of short-term debts to total debts respectively are significant indicators in the model. This is similar to the studies of Lausev et al. (2011), Jedidi (2013), Dawood et al (2017) and Cochrane et al. (2019). Also, the result shows that bmm2, which measures the capacity of the economy to endure reversal in capital flows, was also significant in determining the probability of entering a crisis. Furthermore, the result shows that the inflation rate, foreign asset net open position, and trade openness are all significant in determining the probability of experiencing a financial crisis. For example, rising inflation makes external debt- servicing more expensive than normal, while trade openness makes the African economies susceptible to foreign shock (Caggiano et al., 2014). The positive sign exhibited by the foreign asset net open position may be partly due to the rising level of net foreign asset for four EAEs in recent years. The study also found negative credit growth and capital inflows before the crisis, although it is not significant. This result confirms the significance of a financial stability framework that fits the characteristics of Africa's emerging economies such as rising debt profile, liquidity and currency risk exposure. According to Caggiano et al. (2014), exposure to currency risk is a source of risk to the safety of the financial system. This result implies that EAEs are more likely to collapse when debt rises and there is no capacity to withstand capital flow reversal. Additionally, EAEs are also likely to experience excessive foreign exchange risk due to financial dollarisation.

The second panel of Table 3 focused on the likelihood of lingering in a state of crisis (post-crisis) as against being in a tranquil state. The findings are in accordance with what was expected. For one thing, a negative and statistically significant coefficient for bmm2 shows that a rise in the ratio of money supply to international reserve raises the probability of remaining in a crisis state. Similarly, a positive and significant coefficient for sdtd suggests that rising debt exposure increases the probability or likelihood of the economies remaining in a crisis state. it was revealed that fdi though not significant, is limit the possiblility of the occurrence of crisis within the system.

Table 4. EWS model 2 for emerging African economies using robust standard error

\begin{tabular}{clllllll}
\hline & $\begin{array}{l}\text { Explanatory } \\
\text { variable }\end{array}$ & $\begin{array}{l}\text { Robust } \\
\text { Coef. }\end{array}$ & Std. Err. & $\mathbf{Z}$ & $\mathbf{P}>\mathbf{z}$ & \multicolumn{2}{l}{ [95\% Conf. Interval] } \\
\hline Crisis & & & & & & \\
\hline & Rgdpg & -0.0289 & 0.0183 & -1.5800 & 0.1130 & -0.0647 & 0.006854 \\
\hline Dcrp & -0.0417 & 0.0246 & -1.7000 & $0.0900^{* *}$ & -0.0899 & 0.006463 \\
\hline Infr & 0.2540 & 0.1821 & 1.3900 & 0.1630 & -0.1029 & 0.610856 \\
\hline bmm2 & 0.1784 & 0.0754 & 2.3600 & $0.0180^{*}$ & 0.0305 & 0.326233 \\
\hline Exhr & -0.0119 & 0.0170 & -0.7000 & 0.4820 & -0.0451 & 0.021314 \\
\hline Fxop & 0.0188 & 0.0103 & 1.8300 & $0.0670^{* *}$ & -0.0013 & 0.038856 \\
\hline Dgdp & -0.1863 & 0.0892 & -2.0900 & $0.0370^{*}$ & -0.3610 & -0.0115 \\
\hline Sdtd & 0.3078 & 0.1410 & 2.1800 & $0.0290^{*}$ & 0.0314 & 0.584243 \\
\hline Top & 0.3666 & 0.2278 & 1.6100 & 0.1080 & -0.0798 & 0.813085 \\
\hline Fdi & -0.1807 & 0.2961 & -0.6100 & 0.5420 & -0.7610 & 0.399634 \\
\hline cons & -36.3146 & 19.0282 & -1.9100 & 0.0560 & -73.6092 & 0.980093 \\
\hline Post-Crisis & & & & & & \\
\hline Rgdpg & -0.0046 & 0.0199 & -0.2300 & 0.8160 & -0.0437 & 0.034429 \\
\hline Dcrp & 0.0092 & 0.0090 & 1.0300 & 0.3030 & -0.0083 & 0.026812 \\
\hline Infr & 0.0614 & 0.0643 & 0.9500 & 0.3400 & -0.0646 & 0.187383 \\
\hline bmm2 & 0.1046 & 0.0410 & 2.5500 & $0.0110^{*}$ & 0.0243 & 0.18498 \\
\hline Exhr & -0.0010 & 0.0082 & -0.1200 & 0.9030 & -0.0170 & 0.015 \\
\hline Fxop & 0.0154 & 0.0089 & 1.7300 & $0.0830^{* *}$ & -0.0020 & 0.032822 \\
\hline Dgdp & -0.0602 & 0.0283 & -2.1300 & $0.0330^{*}$ & -0.1157 & -0.00472 \\
\hline & & & & & & \\
\hline & & & & & \\
\hline
\end{tabular}




\begin{tabular}{lllllll}
\hline Sdtd & 0.0246 & 0.0225 & 1.0900 & 0.2750 & -0.0196 & 0.068791 \\
\hline Top & -0.0296 & 0.0324 & -0.9100 & 0.3610 & -0.0931 & 0.03393 \\
\hline Fdi & -0.2848 & 0.2039 & -1.4000 & 0.1630 & -0.6844 & 0.114859 \\
\hline _cons & -6.5254 & 3.4209 & -1.9100 & 0.0560 & -13.2302 & 0.179473 \\
\hline Number of obs & 152 & & & \\
\hline LR chi2(18) & 124.12 & & \\
\hline Prob > chi2 & 0.0000 & & \\
\hline Pseudo R2 & 0.5525 & & \\
\hline Log-likelihood & -50.2572 & & \\
\hline
\end{tabular}

The estimated result of the EWS model using robust standard error is similar to the previous one in Table 3. The result, as presented in Table 4 confirms that dcrp, bmm2, fxop, dgdp, and sdtd are all significant indicators of financial crisis for the crisis period with respect to the tranquil period. The significance of credit growth (dcrp) as a major indicator of crisis is supported in the literature. Wong et al (2010) and Gersl (2018) affirmed that credit growth are major early warning indicator of crisis in the case of 11 Asia-Pacific countries and 36 emerging economies respectively. However, after the crisis, bmm2, fxop, and dgdp are significant indicators of financial crisis with respect to tranquil periods. As noted above, a positive and significant coefficient for sdtd suggests that rising debt exposure increases the probability or likelihood of the economies remaining in a state of crisis. This suggests that African countries are at risk in the light of the rising debt profile, especially debts from China. This raises concerns about African countries defaulting on their debts. According to an IMF report (April 2018), at least 40 percent of low-income countries in the region are either in debt distress or at high risk (Madowo, 2018). Similarly, there was an alarm raised by the China- Africa Research Initiatives in 2015 that there may be a scenario whereby African countries may not be able to pay back loans from China "due to fluctuating commodity prices and decreasing absorptive capacity" (Madowo, 2018). This is a major threat to the economy as it is believed that rising debt profile could discourage potential foreign portfolio investors from investing in the economy. This is because a high debt profile can crash the value of local currency, a scenario that investors would not want to experience.

\subsection{Diagnostic Tests}

The lower panel of Tables 3 and 4 provides evidence on the performance of the multinomial logit model with regards to the predictive strength of the EWS model. Evaluating the goodness-of-fit of the EWS model by observing the Pseudo McFadden $\mathrm{R}^{2}$, the log-likelihood ratio, and the $\mathrm{Chi}^{2}$ Wald test is very important for policymakers. The number of observations used in each regression (N) over the period 1980-2017, the Pseudo McFadden's $\mathrm{R}^{2}$, the log-likelihood ratio, and the $\mathrm{Chi}^{2}$ Wald test are shown in Tables 3 and 4. The pseudo- $\mathrm{R}^{2}$ statistic is useful in assessing the predictive strength of the logistic regression model, i.e. the proportion of variance in the explained variable associated with the explanatory variables. As seen in the result, the pseudo- $\mathrm{R}^{2}$ is 0.55 ; this means that the independent variables can well predict the dependent variable. This is also confirmed by the Wald test statistic which is significant at 5 percent and therefore suggests that the parameters associated with the logistic regression model are simultaneously not zero. This result suggests that the model has good predictive power.

\section{Conclusion and Policy Recommendation}

This study investigated the possibility of creating an early warning signal model aimed at predicting the occurrence of a financial crisis in emerging African countries. The identification and prediction of the state of the financial system are very important for the design of appropriate policy such as countercyclical capital buffers which can help reduce large losses associated with financial crisis. To predict systemic risk in the financial system, an early warning signal (EWS) using multinomial logistic regression was employed. The multinomial logit model reduces the likelihood of false alarm and missed crisis when compared to the binomial logit model. Four emerging African economies (Egypt, Kenya, Nigeria, and South Africa) were considered in the study.

The result shows that debt exposure variables are significant predictors of financial crisis in emerging African countries. African countries are prone to bad debt due to the high cost of repayment of loans from advanced countries and the high level of corruption within the system. It was also noted that money supply, which measures the capacity of the economy to endure reversal in capital flows, was also significant in determining the probability of entering a crisis. Furthermore, the result shows that inflation rate, foreign asset net open position, and trade openness are all significant 
in determining the probability of experiencing a financial crisis. For example, rising inflation makes external debt-servicing more expensive, while, according to Caggiano et al. (2014), trade openness makes African economies susceptible to foreign shock. The result also found negative credit growth and capital inflows before the crisis, although it is not significant.

In summary, the result suggests that emerging African economies are more likely to face financial crisis as debts continue to rise without a corresponding capacity to withstand capital flow reversal. The result further indicates that rising debt exposure as well as excessive foreign exchange risk due to currency exposure increases the likelihood of those economies remaining in a state of crisis. This result confirms the significance of a financial stability framework that addresses the issues confronting Africa's emerging economies such as rising debt profile, liquidity and currency risk exposure. Exposure to currency risk is a source of threat to the soundness of the financial system. Due to data limitations, further studies can incorporate more African economiesto assess the predictability of the model. Sub-samples of countries from different region and sub-periods can as well be estimated.

\section{References}

Babecky, J., Havranek, T., Mateju, J., Rusnak, M., Smidkova, K., \& Vasicek, B. (2014). Banking, debt, and currency crises in developed countries: Stylized facts and early warning indicators. Journal of Financial Stability, 15, 1-17. https://doi.org/10.1016/j.jfs.2014.07.001

Barrell, R., Davis, E. P., Karim, D., \& Liadze, I. (2010). Bank Regulation, Property Prices and Early Warning Systems for Banking Crises in OECD Countries. Journal of Banking \& Finance, 34(9), 2255-2264.

Bhattacharyay, B. N., Dlugosch, D., Kolb, B., Lahiri, K., Mukhametov, I., \& Nerb, G. (2009). Early Warning System for Economic and Financial Risks in Kazakhstan.

Brockmeijer, J., Moretti, M., Osinski, J., Blancher, N., Gobat, J., Jassaud, N., ... Wu, X. (2011). Macro-prudential Policy. An Organizing Framework A paper prepared by the monetary and capital markets department in consultation with Research and other departments. Washington: International Monetary Fund, March 14. Retrieved from www.IMF.org/external/np/pp/eng/2011/031411.pdf

Bussiere, M., \& Fratzscher, M. (2006). Towards a new early warning system of financial crises. Journal of International Money and Finance, 25(6), 953-973.

Caggiano, G., Calice, P., \& Leonida, L. (2014). Early warning systems and systemic banking crises in low-income countries: A multinomial logit approach q. Journal of Banking and Finance, 47, 258-269. https://doi.org/10.1016/j.jbankfin.2014.07.002

Cochrane, S., Ell, K., \& Korobkin, M. (2019). Some Rising Pressure Points in Global Debt. Moody's Analytics. Retrieved from https://www.moodysanalytics.com/-/media/article/2018/global-debt.pdf

Cumperayot, P., \& Kouwenberg, R. (2013). Early warning systems for currency crises: A multivariate extreme value approach. Journal of Iinternational Money and Finance, 36, 151-171.

Cunningham, R. M., \& Friedrich, C. (2016). The role of central banks in promoting financial stability: An international perspective (No. 2016-15). Bank of Canada Staff Discussion Paper.

Daumont, R., Le Gall, F., \& Leroux, F. (2004). Banking in Sub-Saharan Africa: what went wrong? (No. 2004-2055). International Monetary Fund.

Davis, E. P., \& Karim, D. (2008). Comparing early warning systems for banking crises. Journal of Financial Stability, $4(2), 89-120$.

Dawood, M., Horsewood, N., \& Strobel, F. (2017). Predicting sovereign debt crises: an early warning system approach. Journal of Financial Stability, 28, 16-28.

Demirgüç-Kunt, A., \& Detragiache, E. (1998). The determinants of banking crises in developing and developed countries. Staff Papers, 45(1), 81-109.

Drehmann, M., \& Juselius, M. (2014). Evaluating early warning indicators of banking crises: Satisfying policy $\begin{array}{lllll}\text { requirements. International Journal of Forecasting, } & 30(3),\end{array}$ https://doi.org/10.1016/j.jiforecast.2013.10.002

Duttagupta, R., \& Cashin, M. P. (2008). The anatomy of banking crises (No. 8-93). International Monetary Fund.

Eichler, S., \& Sobański, K. (2012). What drives banking sector fragility in the Eurozone? Evidence from stock market data. JCMS: Journal of Common Market Studies, 50(4), 539-560.

Eichler, S., Karmann, A., \& Maltritz, D. (2011). The term structure of banking crisis risk in the United States: a market 
data based compound option approach. Journal of Banking \& Finance, 35(4), 876-885.

Foggitt, G. M., Heymans, A., Van Vuuren, G. W., \& Pretorius, A. (2017). Measuring the systemic risk in the South African banking sector. South African Journal of Economic and Management Sciences, 20(1), 1-9.

Frankel, J. A., \& Rose, A. K. (1996). Currency crashes in emerging markets: An empirical treatment. Journal of International Economics, 41(3-4), 351-366.

Fuertes, A. M., \& Kalotychou, E. (2007). Optimal design of early warning systems for sovereign debt crises. International Journal of Forecasting, 23(1), 85-100.

Geršl, A., \& Jašová, M. (2018). Credit-based early warning indicators of banking crises in emerging markets. Economic Systems, 42(1), 18-31.

Hardin, J. W., Hardin, J. W., Hilbe, J. M., \& Hilbe, J. (2007). Generalized linear models and extensions. Stata Press.

Honohan, P., \& Klingebiel, D. (2003). The fiscal cost implications of an accommodating approach to banking crises. Journal of Banking \& Finance, 27(8), 1539-1560.

Ilesanmi, K. D., \& Tewari, D. D. (2019a). Management of shadow banks for economic and financial stability in South Africa. Cogent Economics \& Finance, 7(1), 1-13. https://doi.org/10.1080/23322039.2019.1568849

Ilesanmi, K. D., \& Tewari, D. D. (2019b). Developing a financial stress index for the Nigerian financial system. African Journal of Business and Economic Research, 14(3), 135-157.

Jedidi, O. (2013). Predicting sovereign debt crises: A panel data approach using composite indices. CREM-CNRS Working Paper, University of Rennes.

Krishnamurti, D., \& Carol Lee, Y. (2014). Macroprudential policy framework: a practice guide. The World Bank.

Laušev, J., Stojanovic, A., \& Todorovic, N. (2011). Determinants of debt rescheduling in Eastern European countries. Economic Annals, 56(188), 7-31.

Louzis, D. P., \& Vouldis, A. T. (2012). A methodology for constructing a financial systemic stress index: An application to Greece. Economic Modelling, 29(4), 1228-1241. https://doi.org/10.1016/j.econmod.2012.03.017

Madowo, L. (2018). How Cambridge Analytica poisoned Kenya's democracy. Washington Post.

Oet, M. V., Bianco, T., Gramlich, D., \& Ong, S. J. (2013). SAFE: An early warning system for systemic banking risk. Journal of Banking and Finance, 37(11), 4510-4533. https://doi.org/10.1016/j.jbankfin.2013.02.016

Savona, R., \& Vezzoli, M. (2015). Fitting and forecasting sovereign defaults using multiple risk signals. Oxford Bulletin of Economics and Statistics, 77(1), 66-92.

Schimmelpfennig, M. A., Roubini, N., \& Manasse, P. (2003). Predicting sovereign debt crises (No. 3-221). International Monetary Fund.

Van den Berg, J., Candelon, B., \& Urbain, J. P. (2008). A cautious note on the use of panel models to predict financial crises. Economics Letters, 101(1), 80-83.

World Bank. (2018). Private Credit by Deposit Money Banks to GDP for South Africa [DDDI01ZAA156NWDB]. Retrieved from https://fred.stlouisfed.org/series/DDDI01ZAA156NWDB

Yellen, J. L. (2011). Macroprudential supervision and monetary policy in the post-crisis world. Business Economics, $46(1), 3-12$.

\section{Notes}

Note 1. The crises years apart from the first year of crisis.

Note 2. This series shows net inflows (new investment inflows less disinvestment) in the reporting economy from foreign investors, and is divided by GDP.

\section{Copyrights}

Copyright for this article is retained by the author(s), with first publication rights granted to the journal.

This is an open-access article distributed under the terms and conditions of the Creative Commons Attribution license (http://creativecommons.org/licenses/by/4.0/). 